Kocatepe Vet J. (2021) 14(1): 65-70

DOI: $10.30607 /$ kvj.855260

RESEARCH ARTICLE

\title{
Determination of Heavy Metal Level in Grey Mullet (Mugil cephalus, Linnaeus, 1758) Fish Caught from Bafa Lake
}

\author{
Süleyman ÖNER ${ }^{1}$, Murat METLذ் ${ }^{2}$ \\ ${ }^{1}$ Muğla Sitke. Koçman University, Milas Vocational School, Hotel Restaurant and Catering Services Department, 48200, \\ Milas/Muğla, Turkey. \\ ${ }^{2}$ Muğla Sitkı Kocman University, Faculty of Milas Veterinary Medicine, Food Hygiene and Technology Department, 48200, \\ Milas/Muğla, Turkey.
}

\begin{abstract}
Seafood are an ideal animal products as adequate and balanced nutrition for human. However, fish affected by environmental pollution maybe transfer the harmful effects of pollution to humans at the end of the food chain. Bafa Lake has been frequently mentioned with the environmental pollution problems in recent years. In this study, the accumulation of copper $(\mathrm{Cu})$, zinc $(\mathrm{Zn})$, iron $(\mathrm{Fe})$, cadmium $(\mathrm{Cd})$, and lead $(\mathrm{Pb})$ heavy metal elements were investigated in the fillet, gonad, liver, and gills of grey mullet fish, which is one of the most caught fish species from Bafa Lake. According to the results obtained, more element concentration levels were determined in the liver and gills than ones in the muscle tissue. $\mathrm{Cu}$ concentration was ranked according to tissues, liver $>$ gill $>$ gonad $>$ fillet form; Zn amount, liver $>$ gonad $>$ gill $>$ fillet form; Fe amount, liver $>$ gill $>$ gonad $>$ fillet shaped; $\mathrm{Cd}$ amount, liver $>$ filet $>$ gill $>$ gonad. The amount of $\mathrm{Pb}$ was found in the form of gonat $>$ liver $>$ filet $>$ gill. It was determined that $16 \% \mathrm{Cd}$ and $68 \% \mathrm{~Pb}$ out of all the muscle tissue in the samples had above the consumable limit respectively. So, these results are a very risky situation for public health. In order to prevent environmental pollution in Bafa Lake and its harmful effects on humans and other living things, it should not be disconnected from the Meander (Büyük Menderes) River, industrial discharges to be made in the Meander River should be done after treatment, and basin management should always be at the forefront in the development works around the lake.
\end{abstract}

Keywords: Heavy Metal, Bafa Lake, Grey Mullet (Mugil cephalus, Linnaeus, 1758), AAS.

\section{Bafa Gölü'nden Avlanan Topan Kefal (Mugil cephalus, Linnaeus, 1758) Türü Balıklarda Ağır Metal Düzeyinin Belirlenmesi}

ÖZ

\begin{abstract}
Su ürünleri yeterli ve dengeli beslenme için ideal hayvansal ürünlerdir. Ancak çevre kirliliğinden etkilenen balıklar, beslenme zincirinin sonundaki insana, kirliliğin zararlı etkilerini aktarabilmektedir. Bafa Gölü, son yıllarda görülen çevre kirliliği problemleriyle adından sıkça söz ettirmektedir. Bu çalışmada, Bafa Gölü'nden en çok avlanan balık türlerinden olan topan kefalin fileto, gonat, karaciğer ve solungaçlarında, bakır $(\mathrm{Cu})$, çinko $(\mathrm{Zn})$, demir $(\mathrm{Fe})$, kadmiyum $(\mathrm{Cd})$ ve kurşun $(\mathrm{Pb})$ elementlerinin birikimleri araştırılmıştır. Elde edilen sonuçlara göre, karaciğer ve solungaçlarda kas dokuya göre daha fazla miktarda element konsantrasyonu belirlenmiştir. Cu konsantrasyonu siralaması dokulara göre, karaciğer $>$ solungaç $>$ gonat $>$ fileto şeklinde; Zn miktarı, karaciğer > gonat> solungaç> fileto şeklinde; Fe yoğunluğu, karaciğer $>$ solungaç $>$ gonat $>$ fileto şeklinde; Cd miktarı, karaciğer $>$ fileto $>$ solungaç $>$ gonat şeklinde; $\mathrm{Pb}$ miktarı ise gonat $>$ karaciğer $>$ fileto $>$ solungaç şeklinde bulunmuştur. Kas doku örneklerinin \%16'sında Cd, \% 68’inde Pb miktarlarının tüketilebilirlik sınırının üzerinde olduğu tespit edilmiştir. Bu sonuç insan sağlığı açısından oldukça riskli bir durumdur. Bafa Gölü’nde çevre kirliliğinin ve bunun insanlara ve diğer canlılara olan zararlı etkilerinin önüne geçebilmek için, gölün Büyük Menderes Nehri ile olan bağlantısı kesilmemeli, Büyük Menderes Nehri’ne yapılacak endüstriyel deşarjlar, arıtım sonrası yapılmalı, göl çevresindeki imar çalışmala rında havza yönetimi hep ön planda olmalıdır.
\end{abstract}

Anahtar Kelimeler: Ağır Metal, Bafa Gölü, Topan Kefal (Mugil cephalus, Linnaeus, 1758), AAS.

To cite this article: Öner S. Metli M. Determination of Heavy Metal Level in Grey Mullet (Mugil cephalus, Linnaeus, 1758) Fish Caught from Bafa Lake. Kocatepe Vet J. (2021) 14(1):65-70

Submission: 07.01.2021 Accepted: 18.02.2021 Published Online: 19.02.2021

ORCID ID; S.Ö.: 0000-0002-0593-9610, M.M.: 0000-0001-9247-3347

*Corresponding author e-mail: muratmetli@mu.edu.tr 


\section{GİRİŞ}

Su ürünleri yeterli ve dengeli beslenme için ideal hayvansal ürünlerdir. Esansiyel aminoasitlere sahip proteinleri, birden fazla çift bağ içeren çoklu doymamış yağ asitlerine sahip lipidleri, çok düşük karbonhidrat miktarı, dengeli bir şekilde içerdiği vitamin ve mineral içeriği ile su ürünleri özellikle de balıklar değerli besinlerdir (Varlık, 2004).

Ancak su ürünlerinin yaşamını sürdürdüğü su ortamları, endüstriyel, zirai ve evsel kaynaklı çevre kirleticilerinin en sonunda biriktiği alıc1 ortamlar olmaktadır (Nassouhi ve ark. 2018). Su canlılarından hareketli olanlar, çevre kirleticilerinin olumsuz etkilerinden temiz alanlara kaçarak nispeten daha az etkilenseler de biyolojik özellikleri nedeniyle sabit yaşam sürdüren su canllları (midye, istiridye v.b.) en çok etkilenenlerdir. Göl, lagün gibi su sirkülasyonunun çok az veya hiç olmadığı kapalı havzalarda ise durum daha da kötü olabilmektedir. Çevresel kirleticiler gölün tamamına sirayet edip, hareketli su canlılarını dahi kontamine ederek zararlı maddelerin organizmalarda birikimine neden olabilmektedir (Luczyńska ve ark., 2018).

Su alıcı ortamlarını kirleten ve canlı ekosisteminde dengeyi bozan kirleticiler, inorganik ve organik yapıda olabilmektedir. $\mathrm{Bu}$ kirleticiler metaller, pestisitler, poliklorlu bifeniller (PCB), polibromlu difenil eterler (PBDE), dioksinler, furanlar ve poliaromatik hidrokarbonlar (PAH)'dır. $\mathrm{Bu}$ kirleticiler, suda yaşayan organizmalara toksik etki yaptığ1 gibi su canlilariyla beslenen, beslenme zincirinin tüm aşamalarındaki canlıları ve insanları da etkilemektedir (Webb ve Gagnon, 2002, Hernández ve ark. 2017).

$5 \mathrm{~g} / \mathrm{cm} 3$ 'ten daha yüksek yoğunlukta ve düșük konsantrasyonlarda bile toksik etkiler gösteren metaller ve metaloidlere ağır metal adı verilmektedir. Bunlardan Bakır $(\mathrm{Cu})$, çinko $(\mathrm{Zn})$, demir $(\mathrm{Fe})$ gibi ağır metaller, canlı vücudunda önemli işlevlerin yerine getirilmesinde görev alırlar ve esansiyel metaller olarak sinıflandirlırlar. Non-esansiyel metaller olarak bilinen kadmiyum (Cd), kurşun $(\mathrm{Pb})$, civa $(\mathrm{Hg})$ gibi ağır metaller ise canlı organizması için bilinen bir fonksiyona sahip olmamasına rağmen, çok düşük dozlarda dahi toksik etkiler gösterebilmektedirler. Bu arada esansiyel metallerin de belirli yoğunluğun üzerinde alındıklarında toksik etki gösterebileceği, gözden kaçırılmaması gereken bir konudur (Järup, 2003, Nassouhi ve ark. 2018).

Topan kefal, tropik ve subtropik sığ sularda yaşayan, zaman zaman haliç ve lagünlere de girip çılkan, ekonomik bir balık türüdür. Hem yetisskin hem de genç balıklar, zooplankton larvaları, organik atıklar ve mikro alglerle beslenirler. Ekolojik açıdan önemli olmalar1 ve gida zincirinde anahtar rol oynamalar1 nedeniyle toksisite çalş̧maları için test organizması olarak kullanılmaktadırlar (Nagarjuna, Mohan, 2017).

Bafa Gölü'nde ekonomik olarak en çok avlanan balık çeşitleri kefal türleridir (Mugil spp.). Kefal türleri içinde de topan kefal öne çıkmaktadır (Şaş1 ve Yabanll, 2015).

$\mathrm{Bu}$ araştırma, Bafa Gölü’nde avlanan topan kefal balıklarında seçilmiş ağır metal $(\mathrm{Cu}, \mathrm{Zn}, \mathrm{Fe}, \mathrm{Cd}, \mathrm{Pb})$ kontaminasyon düzeyinin belirlenmesi amaciyla yapılmıştır.

\section{MATERYAL ve METOT}

\section{Çalışma Alanı}

Bafa Gölü, Ege Bölgesi Kıyı Ege Bölümü’nde antik Milet Şehrinin doğusunda yer alan Türkiye'nin en büyük kıy1 göllerinden biridir (Müllenhoff ve ark., 2004), (Resim 1). Büyük Menderes Nehir Havzasının güneydoğu kesiminde, Teke Dağlarının kuzeyinde, Batı Menteşe Dağlarının batısında bulunan sı̆̆ bir tatlı su gölüdür. Göl, $37^{\circ} 31^{\prime}$ Kuzey, $27^{\circ} 27^{\prime}$ Doğu koordinatlarında yer alır (Şaşı ve Yabanlı, 2015). Antik çağlarda Ege Denizi ile birleşik bir körfez olan (Latmos Körfezi) Bafa Gölü’nün kuzey batı yönünün, Büyük Menderes Nehri'nin taşıdığ1 alüvyonlarla set şeklinde kapatılmasıyla günümüzde göl halini almıştır (Müllenhoff ve ark., 2004).

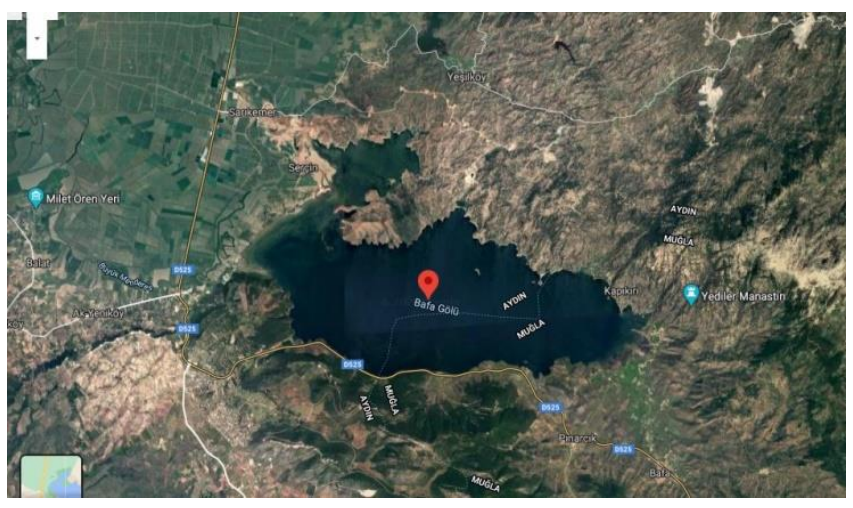

Resim 1: Bafa Gölü Haritası (Yandex Harita)

Figur 1: Bafa Lake Map (Yandex Map)

Örneklerin Toplanması ve Analize Hazırlanması: Bafa Gölü'nden Ekim 2015 ile Mart 2016 arasinda avlanan topan kefal numuneleri, haftada bir steril şartlarda alınıp soğuk zincir içerisinde Muğla Sitkı Koçman Üniversitesi Araştırma Laboratuvarları Merkezine getirilmiştir. Analiz öncesinde balıkların fileto (kas), gonat (eşey organı), karaciğer ve solungaçları diseke edilerek tüm dokuların ayrı ayrı homojenizasyonları yapılmıştır. 24 hafta boyunca örnek alım işlerine devam edilerek 25 örnek toplanmiştır. 
Örneklerin Analizi:

Doku örnekleri, sabit tartıma gelmesi için $120^{\circ} \mathrm{C}$ de kurutulmuştur. Kuru örneklerden $0,5 \mathrm{~g}$ alınmış ve üzerine $8 \mathrm{~mL} \mathrm{HNO}_{3}$ ve $2 \mathrm{~mL} \mathrm{H}_{2} \mathrm{O}_{2}$ ilave edilerek mikrodalga firında (Cem Mars 5) $200{ }^{\circ} \mathrm{C}$ 'de 300 psi basınçta yaş yakma yapilmıştır. $\mathrm{Cu}$, Fe ve $\mathrm{Zn}$ elementlerinin analizi alevli atomik absorbsiyon spektrometrede (AAS) (Agilent240FS AA), Cd ve $\mathrm{Pb}$ elementlerinin analizi ise grafit firın AAS'de (Agilent GTA 120) yapılmıştır.

\section{BULGULAR ve TARTIŞMA}

$\mathrm{Bu}$ çalışmada, toplanan 25 adet topan kefal örneğinden diseksiyonla fileto, gonat, karaciğer ve solungaç dokuları elde edilmiştir. Her bir dokudan 25 adet olmak üzere toplamda 100 dokuda $\mathrm{Cu}, \mathrm{Zn}, \mathrm{Fe}$, $\mathrm{Cd}, \mathrm{Pb}$ elementlerinin düzeylerine bakılmıştır. Topan kefal balık örneklerinin çeşitli organ ve kısımlarında belirlenen ağır metal düzeyleri $(\mathrm{mg} / \mathrm{kg})$ Tablo 1'de gösterilmiştir.

Tablo 1: Topan kefal balık örneklerinin çeşitli organ ve kısımlarında belirlenen ağır metal düzeyleri $(\mathrm{mg} / \mathrm{kg})$ Table 1: Heavy metal levels determined in various organs and parts of topan grey mullet fish samples $(\mathrm{mg} / \mathrm{kg}$ )

\begin{tabular}{|c|c|c|c|c|c|c|}
\hline & & Bakır (Cu) & Çinko (Zn) & $\operatorname{Demir}(\mathrm{Fe})$ & Kadmiyum (Cd) & Kurşun $(\mathrm{Pb})$ \\
\hline \multirow{3}{*}{ Fileto } & $\mathrm{X} \pm \mathrm{Sx}$ & $1,87 \pm 2,25$ & $4,11 \pm 2,08$ & $4,10 \pm 3,28$ & $0,036 \pm 0,104$ & $0,34 \pm 0,15$ \\
\hline & Min & 0,000 & 2,37 & 0,00 & 0,000 & 0,03 \\
\hline & Max & 8,73 & 9,75 & 9,83 & 0,501 & 0,60 \\
\hline \multirow{3}{*}{ Gonat } & $\mathrm{X} \pm \mathrm{Sx}$ & $1,96 \pm 2,28$ & $13,82 \pm 8,23$ & $12,26 \pm 13,21$ & $0,016 \pm 0,044$ & $0,51 \pm 0,44$ \\
\hline & Min & 0,00 & 0,20 & 0,00 & 0,000 & 0,14 \\
\hline & Max & 10,41 & 28,09 & 48,79 & 0,225 & 2,47 \\
\hline \multirow{3}{*}{ Karaciğger } & $\mathrm{X} \pm \mathrm{Sx}$ & $42,33 \pm 38,65$ & $27,10 \pm 23,91$ & $137,24 \pm 78,19$ & $0,128 \pm 0,099$ & $0,39 \pm 0,13$ \\
\hline & Min & 1,71 & 9,88 & 22,24 & 0,000 & 0,15 \\
\hline & Max & 165,33 & 115,54 & 311,78 & 0,377 & 0,56 \\
\hline \multirow{3}{*}{ Solungaç } & $\mathrm{X} \pm \mathrm{Sx}$ & $7,85 \pm 16,38$ & $12,72 \pm 5,15$ & $58,51 \pm 21,87$ & $0,028 \pm 0,075$ & $0,34 \pm 0,13$ \\
\hline & Min & 0,00 & 1,33 & 8,04 & 0,000 & 0,08 \\
\hline & $\operatorname{Max}$ & 58,94 & 28,05 & 114,19 & 0,322 & 0,50 \\
\hline
\end{tabular}

Elde edilen element konsantrasyonlarının dokulara göre dağılımı incelendiğinde karaciğer ve solungaçlarda kas dokuya göre daha fazla miktarda element belirlenmiştir. Cu konsantrasyonu sıralaması dokulara göre, karaciğer $>$ solungaç $>$ gonat $>$ fileto şeklinde; Zn miktarı, karaciğer $>$ gonat $>$ solungaç $>$ fileto şeklinde; Fe yoğunluğu, karaciğer $>$ solungaç $>$ gonat $>$ fileto şeklinde; Cd miktarı, karaciğer $>$ fileto $>$ solungaç $>$ gonat şeklinde; $\mathrm{Pb}$ miktarı ise gonat $>$ karaciğer $>$ fileto $>$ solungaç şeklinde bulunmuştur.

Türkiye ve Avrupa Birliği mevzuatında, bu çalışmada incelenen ağır metallerden sadece $\mathrm{Cd}$ ile $\mathrm{Pb}$ için balıklarda tüketilebilirlik sınırı belirlendiğinden söz konusu elementlerde bu mevzuata göre değerlendirme yapılmıştır (Türk Gıda Kodeksi Bulaşanlar Yönetmeliği, 1881/2006/EC). Cu, Zn ve Fe için ise Birleșmiș Milletler Gıda ve Tarım Örgütü (FAO) ve
Dünya Sağlık Örgütünün (WHO) bildirdiği tüketilebilirlik sınırı dikkate alınmıştır (FAO/WHO, 1989; Asgedom ve ark., 2012). Mevzuatta limitler yaş ağırlık üzerinden verildiği için karşılaştırma yapılabilmesi için çalışmamızda kuru madde oranı üzerinden elde edilen sonuçlar, rutubet oranı kullanılarak düzeltilmiştir.

Buna göre yenilebilir kısım olan filetolarda, $\mathrm{Cu}, \mathrm{Zn}$ ve $\mathrm{Fe}$ miktarı tespit edilemeyen örnekler olduğu gibi tüketilebilir limitin üzerinde miktara rastlanmamıștır. Gonatlarda da $\mathrm{Cu}, \mathrm{Zn}$ ve Fe miktarı tespit edilemeyen örnekler olduğu gibi tüketilebilir limitin üzerinde miktara rastlanmamıştır. Fileto örneklerinin \%16'sinda $\mathrm{Cd}, \quad \%$ 68'inde $\mathrm{Pb}$ miktarlarının tüketilebilirlik sınırının üzerinde olduğu tespit edilmiștir. Gonatların \% 4'ünde $\mathrm{Cd}, \% 80$ 'inde $\mathrm{Pb}$ miktarlarının tüketilebilirlik sınırının üzerinde olduğu 
tespit edilmiştir. Karaciğer örneklerinin \% 56'sında $\mathrm{Cu}$ ve $\mathrm{Fe}, \%$ 12'sinde $\mathrm{Zn}, \%$ 76'sinda Cd, \% 72'sinde $\mathrm{Pb}$ miktarlarının tüketilebilirlik sınırının üzerinde olduğu görülmüştür. Solungaçların da \% 16'sında Cu, $\%$ 4'ünde $\mathrm{Fe}, \%$ 12'sinde $\mathrm{Cd}$, \% 64'ünde $\mathrm{Pb}$ miktarlarının tüketilebilirlik sınırının üzerinde olduğu belirlenmiştir. Solungaçların hiçbiri $\mathrm{Zn}$ açısından tüketilebilirlik sınırını aşmamıştır.

Bafa Gölü ve Büyük Menderes Nehri'nin bağlantısı iki kanal vasıtası ile sürdürülmektedir. Böylece gölün taze su giriş çıkışı sağlanmaktadır. Ancak tarımsal sulama faaliyeti için Büyük Menderes Nehri'nin suyuna ihtiyaç duyulduğu sezonlarda (yılda yaklaşık 5-6 ay) bu bağlantı kesilmekte ve Bafa Gölü'nün su sirkülasyonu engellenmektedir. Ayrıca Büyük Menderes Nehri'nin beslendiği Afyon, Uşak, Aydın ve Denizli havzalarından kaynaklanan evsel, endüstriyel ve tarımsal faaliyet atıkları nehir vasıtasıyla Bafa Gölü'ne taşınmaktadır. Göle ulaşan atıklar kanal tabanına göre daha derin olan Bafa Gölü'nde birikmektedir (Anonim, 2018; Kesici ve Kesici, 2014). Gölün yakin havzasında yapılan tarımsal faaliyetler, zeytinyağ1 üretim tesisleri, turistik tesis kaynaklı atıklar ile evsel atıklar da gölün kirliliğini arttıran unsurlardır (Kesici ve Kesici, 2014).

Çevre kirliliği doğrudan temas halindeki canlıları etkilediği gibi beslenme zinciri vasitasıyla kirlilik odağından uzak yaşayan insanları da olumsuz etkileyebilmektedir. Çevre kirliliğini oluşturan başat unsurlardan ağır metaller arasında insan sağlı̆̆ını olumsuz etkileyen $\mathrm{Pb}$ ve $\mathrm{Cd}$ önemli elementler olmakla birlikte; Fe, $\mathrm{Cu}$ ve $\mathrm{Zn}$ elementleri de canlilar için esansiyel fakat belirli düzeyin üzerinde alındığında yine insan sağlı̆̆ını olumsuz etkileyebilmektedir (Yipel ve Yarsan 2014).

Ağır metal birikimi, kas dokularda, diğer doku ve organlara göre (karaciğer, gonat ve solungaç gibi) daha az olmasina rağmen kas dokunun gida olarak tüketilen kısım olması nedeniyle buradaki birikim daha önemlidir. Balıklarda solungaçlar, çözünmüş metalin organizmaya girdiği yer ve karaciğer de detoksifikasyonunun gerçekleştirildiği organ olduğu için ağır metal yoğunluğuna bu iki organda daha çok rastlanabilmektedir (Yipel, 2012).

Y1lmaz (2009) Köyceğiz Gölü’nden yakalanan 44 adet topan kefal örneğinde $\mathrm{Cu}, \mathrm{Zn}$, Cd ve $\mathrm{Pb}$ elementlerini indüktif eşleşmiş plazma atomik emisyon spektroskopisi (ICP/AES) ile araştırmış ve örneklerin kas dokularında $\mathrm{Cu}, \mathrm{Zn}, \mathrm{Cd}$ ve $\mathrm{Pb}$ miktarlarını ortalama olarak sirasiyla 6,$34 ; 98,6 ; 0,12 ; 0,43 \mathrm{mg} / \mathrm{kg}$; karaciğer dokularında 749,76; 402,61; 3,32; 0,78 $\mathrm{mg} / \mathrm{kg}$; solungaçlarında da 5,68; 176,93;0,37; 1,96 $\mathrm{mg} / \mathrm{kg}$ düzeyinde olduğunu bildirmiştir. Bizim çalışmamızda ise tüm ağır metallerin daha düşük tespit edildiği gözlenmektedir.

Yabanlı ve ark. (2013) Bafa Gölü'nden elde edilen 22 adet levreğin kas, karaciğer ve solungaçlarında $\mathrm{Cu}, \mathrm{Cd}$, ve $\mathrm{Pb}$ elementlerinin miktarını indüktif eşleşmiş plazma kütle spektroskopisi (ICP-MS) ile analiz etmiş ve kas dokularında $\mathrm{Cu}, \mathrm{Cd}$, ve $\mathrm{Pb}$ yoğunluğunu ortalama olarak sirasiyla 0,$61 ; 0,05 ; 0,23 \mathrm{mg} / \mathrm{kg}$; karaciğer dokularında 1,09; 0,02; 0,25 mg/kg; solungaçlarda 0,$48 ; 0,04 ; 0,34 \mathrm{mg} / \mathrm{kg}$ olarak tespit etmişlerdir. Kas dokudaki ağır metal oranı bizim çalışmamızla benzerlik göstermektedir. Ancak karaciğerde özellikle $\mathrm{Cu}$ yoğunluğunun bizim çalışmamıza göre daha fazla olduğu görülmektedir.

Aydın-Önen ve ark. (2015) Bafa Gölü'nden Eylül 2010 ile Mayıs 2011 arasinda toplanan topan kefal balıklarında ağır metal miktarlarını AAS ile analiz etmişler, kas dokularında $\mathrm{Cu}, \mathrm{Zn}, \mathrm{Cd}$ ve $\mathrm{Pb}$ elementlerini surasiyla ortalama 1,$18 ; 16,01 ; 0,02 ; 0,73$ $\mathrm{mg} / \mathrm{kg}$; karaciğerlerinde de 190,62;160,31;0,59;0,57 $\mathrm{mg} / \mathrm{kg}$ bulmuşlardır. Aydın-Önen ve arkadaşlarının çalışmasında ağır metal oranının bir miktar fazla olduğu gözlenmektedir.

Bayhan ve Ünübol Aypak (2016) Büyük Menderes Nehri'nin Deltasinda avlanan kefal örneklerini indüktif eşleşmiş plazma-optik emisyon spektrometresi (ICP-OES) ile analiz etmişler ve kas dokularında $\mathrm{Cu}, \mathrm{Zn}$ ve $\mathrm{Cd}$ konsantrasyonunu sirasiyla ortalama 25,21; 101,83; 6,07 mg/kg; karaciğerlerinde 378,56;527,60; 9,13 mg/kg olarak tespit etmişlerdir. Ağır metal miktarının hem kas dokuda hem de karaciğerde bizim çalışmamızdan oldukça yüksek olduğu görülmektedir.

Damodharan ve Reddy (2013) kurak ve yağ1şl mevsimlerde olmak üzere Hindistan Uppanar Nehri'nin aşağ1 ve yukarı kesimlerinden elde edilen 56 adet topan kefalin kas dokularında $\mathrm{Cu}, \mathrm{Zn}, \mathrm{Cd}$ ve $\mathrm{Pb}$ elementlerinin yoğunluğuna AAS ile analiz etmişlerdir. Kurak mevsimde Uppanar Nehri'nin yukarı kesiminden elde edilen balıklarda $\mathrm{Cu}, \mathrm{Zn}, \mathrm{Cd}$ ve $\mathrm{Pb}$ elementlerini sirasiyla ortalama 0,04; 14,09; 0,$01 ; 0,055 \mathrm{mg} / \mathrm{kg}$, aşağ 1 kesiminden elde edilen balıklarda aynı elementleri 0,$18 ; 16,26 ; 0,01 ; 0,19$ $\mathrm{mg} / \mathrm{kg}$ tespit etmişlerdir. Yağışlı sezonda yukarı kesimden avlanan örneklerde yine $\mathrm{Cu}, \mathrm{Zn}, \mathrm{Cd}$ ve $\mathrm{Pb}$ elementlerini sirasiyla ortalama 0,$02 ; 3,11 ; 0,002 ; 0,02$ $\mathrm{mg} / \mathrm{kg}$; aşağı kesimden elde edilen balıklarda 0,13 ; 8,32;0,01;0,10 mg/kg olarak tespit etmişlerdir. Bu çalışmada Zn miktarının bizim çalışmamıza göre yüksek diğer ağır metallerin ise düşük olduğu gözlenmektedir.

Krishna ve ark. (2014) Hindistan, Machilipatnam Sahili'nden toplanan topan kefal örneklerinde $\mathrm{Cu}, \mathrm{Zn}$, 
Cd elementlerinin miktarını AAS ile araştırmışlardır. Balıkların kas dokularında $\mathrm{Cu}, \mathrm{Zn}$, Cd elementlerinin yoğunluğunu sirasiyla ortalama 25,21; 101,83; 6,07 $\mathrm{mg} / \mathrm{kg}$; karaciğerlerde 378,$56 ; 527,60$ ve $9,13 \mathrm{mg} / \mathrm{kg}$ tespit etmişlerdir. Bizim çalışmamıza göre Krishna ve arkadaşlarının bulduğu sonuçlar oldukça yüksek görülmektedir.

Makedonski ve ark. (2017) Bulgaristan'ın Kara Deniz kıylarından elde ettikleri 6 adet topan kefalde $\mathrm{Cu}, \mathrm{Zn}$, $\mathrm{Cd}$ ve $\mathrm{Pb}$ elementlerini AAS ile analiz etmişler ve kas dokuda $\mathrm{Cu}, \mathrm{Zn}, \mathrm{Cd}$ ve $\mathrm{Pb}$ miktarını sirasiyla ortalama 0,$34 ; 5,2 ; 0,012 ; 0,05 \mathrm{mg} / \mathrm{kg}$; solungaçlarda ise 0,96 ; 7,3; 0,013; 0,07 $\mathrm{mg} / \mathrm{kg}$ bulmuşlardır. Bizim araştırmamıza göre bu araştırmada bulunan ağır metal içeriklerinin düşük olduğu görülmektedir.

Bizim çalışmamız ile diğer araştırma sonuçları arasındaki farklılıkların sebebinin, alıcı ortamların kirlilik düzeylerinin değişken olması, balık türleri arasındaki metabolizma farklılığı, ağır metal miktarı hesabının kuru ağırlık üzerinden yapılması, çalışmanın su debisinin azaldığı ve ağır metal konsantrasyonunun yükseldiği yaz aylarında yapılmış olması gibi sebeplerden kaynaklanabileceği düşünülmektedir.

\section{SONUÇ}

Bafa Gölü’nde yaptığımız bu çalışmada özellikle iz elementlerden olan $\mathrm{Cd}$ ve Pb'nin balığın yenilebilir kısımlarında, mevzuatta belirtilen tüketilebilir limitlerin üstünde olduğu görülmektedir. Bu sonuç insan sağllğı açısından oldukça riskli bir durumdur. Bilinçli veya bilinçsiz olarak doğaya bırakılan atıklar, genel olarak beslenme zincirinin son halkası olan insana sağlık riski olarak geri yansımaktadır. Beslenme yoluyla organizmaya alınan ağır metallerin sağlığa olan etkilerinin uzun vadede ortaya çıkması, bu sorunun göz ardı edilmesine sebep olmaktadır. Bafa Gölü'nde kirliliğin önlenebilmesi için Büyük Menderes ile olan bağlantısının kesilmemesi gerekmektedir. Ayrıca çok geniş bir havzanın alıcı ortamı olan Büyük Menderes Nehri'ne yapılacak endüstriyel deşarjlar, arıtım sonrası yapılmalıdır. Bafa Gölü'nün ve Büyük Menderes Nehri'nin kirlilik parametreleri bir plan dahilinde izlenmelidir. Tarımsal ilaç kutularının, ilaçlama alet ve ekipmanların temizliği; atıklarının alıcı ortamlara (akarsu, göl) ulaşacağı şekilde yapılmamalıdır. Bunun için çok geniş bilgilendirme kampanyaları düzenlenmelidir. Göl çevresindeki imar çalışmalarında havza yönetimi hep ön planda olmalıdır. Artık, çevre kirliliği göz zevkini bozan bir durum olmaktan çıkmıs, insan sağlığına kasteden bir vaka haline gelmiştir.

Çıkar çatışması: Yazarlar bu yazı için gerçek, potansiyel veya algılanan çıkar çatışması olmadı̆̆ını beyan etmişlerdir.
Etik izin: Bu çalışma "Hayvan Deneyleri Etik Kurullarının Çalışma Usul ve Esaslarına Dair Yönetmelik" Madde 8 (k) gereği HADYEK iznine tabi değildir.

Finansal destek: Bu çalışma Muğla Sitk1 Koçman Üniversitesi Bilimsel Araştırma Projeleri Koordinasyon Birimi tarafindan "15/069" proje numarası ile desteklenmiştir.

Açıklama: $\mathrm{Bu}$ çalışmada desteklerini veren Muğla Sıtk1 Koçman Üniversitesi Gıda Analizleri Uygulama ve Araştırma Merkezi araştırmacılarına Teşekkürlerimizi sunarız.

\section{KAYNAKLAR}

Anonim, Aydın Büyükşehir Belediyesi. Aydın-2040, 1/25.000 ölçekli nazım imar planı açıklama raporu. 2018. Erişim Adresi: https://aydin.bel.tr/ Content/assests/Videolar/2312019143104.pdf

Asgedom AG, Desta MB, Gebremedhin YW. Bioaccumulation of heavy metals in fishes of Hashenge Lake, Tigray, Northern Highlands of Ethiopia, American Journal of Chemistry, 2012; 2(6): 326-334.

Aydın-Önen S, Küçüksezgin F, Koçak F, Açık S. Assessment of heavy metal contamination in Hediste diversicolor (O.F. Müller, 1776), Mugil cephalus (Linnaeus, 1758), and surface sediments of Bafa Lake (Eastern Aegean), Environ Sci Pollut Res., 2015; 22:8702-8718.

Bayhan T, Ünübol Aypak S. Büyük Menderes Deltasindan avlanan kefal ve levreklerde $\mathrm{Cu}, \mathrm{Zn}$ ve $\mathrm{Cd}$ düzeylerinin belirlenmesi ve metallotiyonin ile ilişkisinin araştırılması, GIDA, 2016; 41 (5): 359-365

Commission Regulation 2006/1881/ EC European Commission (2006) setting maximum levels for certain contaminants in foodstuffs, Brussels.

Damodharan U, Reddy M.V. Heavy metal bioaccumulation in edible fish species from an industrially polluted river and human health risk assessment, Arch. Pol. Fish., 2013; 21: 19-27.

Hernández ÁR, Camacho M, Henríquez-Hernández LA, Boada LD, Valerón PF, Zaccaroni A, Zumbado M, Almeida-González M, RialBerriel C, Luzardo OP. Comparative study of the intake of toxic persistent and semi persistent pollutants through the consumption of fish and seafood from two modes of production (wildcaught and farmed). Science of the Total Environment, 2017;575: 919-931.

Järup L. Hazards of heavy metal contamination, British Medical Bulletin, 2003; 68: 167-182

Kesici E ve Kesici C. Bafa Gölü Tabiat Parkında yaşam son bulurken son çığlık eylemi, Tabiat ve İnsan, 2014; 48(188): 25-31 
Krishna PV, Madhusudhana Rao K, Swaruparani V. Heavy metals concentration in fish Mugil cephalus from Machilipatnam Coast and Possible Health Risks to Fish Consumers, British Biotechnology Journal, 2014; 4(2): 126-135

Łuczyńskaa J, Paszczyka B, MJ. LuczyńskiMJ. Fish as a bioindicator of heavy metals pollution in aquatic ecosystem of Pluszne Lake, Poland, and risk assessmen for consumer's health, Ecotoxicology and Environmental Safety, 2018; 153:60-67.

Makedonski L, Peycheva K, Stancheva M. Determination of heavy metals in selected black sea fish species, Food Control , 2017; 72: 313-318.

Müllenhoff $\mathbf{M}$, Handl M, Knipping $\mathbf{M}$, Brückner $\mathbf{H}$. The evolution of Lake Bafa (Western Turkey)Sedimentological, microfauna land palynological results, 2004;Coastline Rep 1:55-66.

Nagarjuna A, MohanD. Biochemical and histopathological changes induced by nickel in the striped mullet, Mugil cephalus (Linnaeus 1758), Bull Environ Contam Toxicol. 2017; 98: 33-40.

Nassouhi D, Ergönül MB, Fikirdeşici Ş, Karacakaya P, Atasağun S. Ağır metal kirliliğinin biyoremediasyonunda bazı su içi ve yüzücü sucul makrofitlerin kullanımı, Süleyman Demirel Üniversitesi Eğirdir Su Ürünleri Fakültesi Dergisi, 2018; 14(2), 148-165.

Şaşı H, Yabanlı M. Bafa Gölü’nün biyo-çeşitliliği ve çevresel sorunları, Tuna M, (Proje Yürütücüsü) Bafa Gölü Havzasında toplum destekli ekoturizm faaliyetlerinin belirlenmesi projesi sonuç raporu, Proje No: GEKA TR32 14 DFD 0043, 2015; Erişim adresi: https://geka.gov.tr/uploads/pages_v/bafa-goluhavzasinda-toplum-destekli-ekoturizmfaaliyetlerinin-belirlenmesi-2014.pdf

Türk Gıda Kodeksi Bulaşanlar Yönetmeliği (2011, 29 Aralık). Resmi Gazete (Sayı: 28157 (3. Mükerrer)). Erişim adresi: https://www.resmigazete.gov.tr/eskiler/2011/12/2 0111229M3-8.htm

Varlık C, Erkan N,Baygar T. Su ürünleri besin bileşimi, In Su ürünleri işleme teknolojisi, Ed; Varlık C. İstanbul Üniversitesi Yayınlar1, Yayın No:4465, İstanbul, 2004; p.p. 1-43.

Webb D, Gagnon M.M. Biomarkers of Exposure in fish inhabiting the swan-canning Estuary, Western Australia- A Preliminary Study, Journal of Aquatic Ecosystem Stress and Recovery, 2002; 9:259-269.

WHO/FAO. National Research Council Recommended Dietary 626 Allowances (10th ed). National Academy Press. Washington, DC. USA. 1989.

Yabanlı M, Coşkun Y, Öz B, Yozukmaz A, Sel F, Öndeş S. Bafa Gölü'nden elde edilen levreklerde (Dicentrarchus Labrax) ve göl suyunda ağır metal içeriğinin belirlenmesi ve balık/halk sağlı̆̆1 açısından durum değerlendirmesi, Bornova Vet. Bil. Derg., 2013; 35 (49): 15-23.
Yandex Harita. (2020) Bafa Gölü Haritası [Harita]. Erişim Adresi:https://yandex.com.tr/harita/983/turkey/g eo/bafa_golu/2525113833/?l=sat $\% 2$ Cskl\&ll $=27.45$ $3045 \% 2 \mathrm{C} 37.515059 \& z=12$

Y1lmaz F. The comparison of heavy metal concentrations $(\mathrm{Cd}, \mathrm{Cu}, \mathrm{Mn}, \mathrm{Pb}$, and $\mathrm{Zn})$ in tissues of three economically important fish (Anguilla anguilla, Mugil cephalus and Oreochromis niloticus) inhabiting Köycegiz Lake-Mugla (Turkey), Turkish Journal of Science \& Technology, 2009; Volume 4, No 1: 7-15.

Yipel M, Yarsan E. A Risk Assessment of heavy metal concentrations in fish and an invertebrate from the Gulf of Antalya, Bull Environ Contam Toxicol., 2014; 93:542-548

Yipel M. Akdeniz Antalya Körfezi'nde avlanan barbunya (Mullus barbatus, Linnaeus, 1758), kefal (Mugil cephalus, Linnaeus, 1758), yeşil kaplan karidesi (Panaeus semisulcatus, De Haan, 1844) türlerinde baz1 ağır metal düzeylerinin belirlenmesi (Doktora Tezi) 2012. Erişim Adresi: https://dspace.ankara.edu.tr/ xmlui/handle/20.500.12575/35394 